\title{
FORMAL AND NON-FORMAL EDUCATION IMPACT ON DEVELOPING MARKETING MANAGER COMPETENCE IN THE DIGITAL AGE
}

\author{
Gordana Tasevska ${ }^{1}$ \\ Dijana Ivanovska Przo ${ }^{2}$
}

DOI: https://doi.org/10.31410/LIMEN.2020.279

\begin{abstract}
Digital marketing enables companies to be virtual, in relation to customers. Modern working conditions require skillful and knowledgeable digital managers, developed competence, as well as great motivation for lifelong learning.

Digital marketing managers collect potential customers' data, conduct online research and direct development, implementation and management of online campaigns that promote a particular company and its products or services.

This paper will give a deep insight into the competence of digital managers as a result of an acquired degree in this field or as a result of additional courses, training and online activities of a determined person.

The combination of both alternatives is a third option that contributes to the goal of the scientific proof in the paper.
\end{abstract}

Keywords: Competence, Digital marketing, Manager.

\section{INTRODUCTION}

7 he transfer of theoretical working knowledge into practical knowledge stresses the need for a workforce that not only possesses specialized knowledge relevant to the work post but will also possess developed generic knowledge and skills in order to adapt to new technologies and change the reality into which it manifests itself. Today, within the frames of digital age, more than ever, it is of crucial importance for all employees in organization to receive high quality education and training in order to be equipped with key competencies needed to be virtual in relation to users. Digital marketing is a form of marketing promotion and sales of goods and services on the Internet. It represents a process of utilizing a range of network marketing channels such as search engines, social media networks and e-mail to reach the target audience.

Digital marketing managers collect details for potential clients, conduct online research, are responsible for the development, implementation and management of online campaigns that promote a particular company and its products or services.

The contemporary working conditions require digital managers to have considerable knowledge and skills, developed competencies, as well as great motivation for lifelong learning. In the Key Competencies For Lifelong Learning - A European Reference Framework (2007), competencies are defined as "a combination of knowledge, skills and attitudes relevant

Business Academy Smilevski BAS, Skopje, North Macedonia

Business Academy Smilevski BAS, Skopje, North Macedonia 
to the context. Key competencies are those that each individual needs for personal fulfilment and development, active citizenship, social inclusion and employment."

\section{DEVELOPMENT OF KEY COMPETENCIES THROUGH NON-FORMAL AND FORMAL EDUCATION}

In accordance with a large number of international studies, "competencies" are most often defined as a combination of knowledge, skills and attitudes that will be the basis for personal development and fulfillment, for active citizenship and inclusion, as well as for employment. ${ }^{3}$ People should develop their competencies throughout their lives. The foundations of lifelong learning will be laid during the basic upbringing and education which should help the students to acquire the key competencies and to enable them to live in the modern society. The competencies framework should be observed from a long-term perspective. At the European level, it will move towards identifying a balanced list of key competencies that will be necessary for:

1. Self-realization and development throughout life (cult capital). Key competencies must enable individuals to realize individual goals based on personal interests and aspirations and with a desire to continue lifelong learning,

2. Active civic awareness and involvement i.e. social inclusion (social capital). Key competencies should enable each individual to participate in society as an active citizen,

3. The ability for employment (human capital). Capacity building of each person to find a decent job in the labor market. ${ }^{4}$

Key competencies are a transferable, multifunctional package of knowledge, skills and attitudes that are necessary for all, for personal realization and development, inclusion and employment. They should be developed by the time compulsory education or training ends and should be the basis for further learning as part of lifelong learning. ${ }^{5}$

When we talk about learning, without exception, we concentrate on the processes that take place in schools and universities. However, a significant part of the process of acquiring knowledge takes place outside the classrooms, i.e. outside the formal education system. UNESCO defines the term education as any deliberate and systematic activity designed to meet the learning needs, including what in some countries is referred to as cultural activity or training. ${ }^{6}$ The main goal of this education/learning is to acquire competencies for a job.

Formal education is a systematic, organized educational process based on a defined educational model and established educational levels and subsystems. This type of education is structured and administered according to a given set of laws and norms, based on the presentation of a rather inflexible program in relation to the goals, contents and methodology, which must include the teacher, the student and the institution. For the completion of levels of formal education, one receives a certificate as a document that ensures continuing the education at higher education level (certificate for completed primary education and enrollment in

Rizova, E. (2015), Lifelong learning (internal material), Skopje: Faculty of Philosophy, p.17

European Commision.(2004). Key competences for lifelong learning, European reference framework, implementation of "Education and training 2010" work programme, Brussels, p.3.

Pandilovska, S. (2011), Key Competences for Lifelong Learning in the Context of Secondary Education (doctoral thesis), Skopje: Faculty of Philosophy, p.16

https://nfoaktiv.wordpress.com/2010/06/10/ 
secondary education), i.e. a diploma for completed education which enables entry into the labor market or continuation at higher levels of education. ${ }^{7}$

Informal education was defined by UNESCO in 1972 as "educational activity, outside the formal system, which aims to meet the needs of users, but also the goals of learning." Today, informal education and learning become a necessity as it enables adults and young people to keep up with the development of society and compensates for what lacks in formal education and learning.

Lately, the importance of recognition and validation of competencies in a larger number of European countries has been increasingly emphasized. People often start a certain learning process and then abandon it. During that time, they acquire certain knowledge and skills, which are lost in the space of educational abstinence. Young people and adults acquire knowledge and skills in a formal, informal and non-formal way. Significant funds, energy and time are invested in this process, which are not evaluated and which do not enable meeting of the formal conditions for employment and/or work. Such a reality, that knowledge and skills are created outside formal education and training, has caused almost all countries in Europe to develop legal provisions for their recognition, regardless of whether they are acquired in formal, informal or non-formal ways. Such a policy encourages employment and inclusion, while strengthening the self-confidence of individual users. On the other hand, the new framework for the recognition of informal learning requires reforms to introduce a quality assurance system and strengthen the necessary trust: to build new forms of competency-based assessment and flexible and modularized training, and to empower individuals and institutions who are prepared to participate in and benefit from this new paradigm.

\section{COMPETENCIES OF MARKETING MANAGERS IN THE DIGITAL AGE}

One of the most dynamic fields within the management arena in which the market continuously presents new challenges, and to which companies must respond, is strategic marketing. Therefore, it is not surprising that new market ideas are constantly on the surface to meet new market challenges. The marketing strategy is a long-term plan to achieve the goals of the organization.

The evolution of strategic marketing as a field of study over the past few decades can be seen as a set of perspectives, paradigms, theories, concepts, frameworks, principles, methods, models and parameters of a number of related study areas. Until today, this field is expanding. A digital marketing strategy provides the owners of organizations with the best chances for competition, survival and even business growth. Digital marketing encompasses all marketing efforts using electronic devices or the Internet. Businesses use digital channels such as search engines, social media, e-mail and other websites to connect with current and potential clients.

Within each organization, there should be a management team that will work effectively on the way of developing and implementing and realizing functional digital marketing strategies.

A team that will be responsible for developing, implementing and overseeing long-term digital marketing campaigns, as well as short-term advertising techniques. Being skilled in improving brand awareness, increasing website traffic and generating sales leaders is just some of the

Petkovski, K., Terzioska, V., Stefanovska, L. (2014), Active Bitola: PEN-KM Bitola, HerakliKomerc Bitola, p.3. 
knowledge that must be possessed. The digital marketing manager oversees the marketing team and provides support in several areas, such as:

$>$ Identifying and testing new digital platforms and tools;

$>$ Using web analytics tools to track site traffic;

$>$ Optimizing marketing campaigns, including e-mail marketing, social media marketing and digital advertising;

Monitoring consumer behavior.

Today, in this dynamic labor market society, apart from diplomas, certificates and qualifications are an important reference for digital marketing managers. Knowledge, skills, abilities are the most important thread they need. In terms of soft skills, digital marketing managers need to:

Think strategically - This skill involves understanding customers, i.e. directing, advertising and optimizing campaigns.

Manage time - Digital marketing managers need to create a system for timely task completion. Communicate - Digital marketing managers must possess powerful, clear and concise communication skills to succeed in their field. A qualified communicator uses features such as active listening, positivity and patience, as well as verbal and written communication skills.

Possess interpersonal skills - These skills are often a combination of written and verbal communication aimed at facilitating clear, respectful communication with the media, sales leaders, colleagues and customers.

Acquire technical skills - Digital marketing managers must keep pace with the forms of technology they use in a daily set of tasks. They must acquire the technical skills to use the equipment, software and online platforms needed to carry out their work effectively.

Digital managers need to be adaptable, interested in learning new digital techniques, innovative in their work and following trends, be leaders, take initiatives, be creative problem solvers and be focused on doing business.

\section{CONDUCTED RESEARCH}

For the purposes of the research, the test method has been used. That is, as a technique, a survey has been conducted with a structured questionnaire. 30 managers in organizations from different industries and sectors in the Republic of North Macedonia have been surveyed in order to determine how formal and informal education affect the competencies of digital marketing managers. The analysis of the obtained data from the questionnaires has been processed in the statistical software package SPSS Statistic and a discriminatory nonparametric procedure has been used, i.e. $\chi^{2}$ test to determine the quality of eligibility (deviations from the expected and observed statements frequencies).

According to the results obtained from the conducted research on the attributive indicators, deviations have been determined, i.e. statistically significant differences in three indicators, and they have not been observed only in one, indicated by the obtained values:

$\checkmark$ Formal education, with Sig. $=.001$;

$\checkmark$ Informal education, with Sig. $=.000$;

$\checkmark$ Digital trends, with Sig. $=.000$;

$\checkmark$ Digital platforms and tools, with Sig. $=.238$; 
Table 1. Formal education VAR00001

\begin{tabular}{|c|c|c|c|c|c|}
\hline & Observed N & Expected N & Residual & & VAR00001 \\
\hline $\mathbf{1 , 0 0}$ & 29 & 18,6 & 10,4 & Chi-Square & $18,129^{\mathrm{a}}$ \\
\hline $\mathbf{2 , 0 0}$ & 20 & 18,6 & 1,4 & & \\
\hline $\mathbf{3 , 0 0}$ & 15 & 18,6 & $-3,6$ & & \\
\hline $\mathbf{4 , 0 0}$ & 5 & 18,6 & $-13,6$ & df & 4 \\
\hline $\mathbf{5 , 0 0}$ & 24 & 18,6 & 5,4 & & \\
\hline Total & 93 & & & Asymp. Sig. &, 001 \\
\hline
\end{tabular}

Table 2. Non-formal education VAR00002

\begin{tabular}{|c|c|c|c|c|c|}
\hline & Observed N & Expected N & Residual & & VAR00002 \\
\hline $\mathbf{1 , 0 0}$ & 10 & 13,0 & $-3,0$ & Chi-Square & $20,462^{\mathrm{b}}$ \\
\hline $\mathbf{2 , 0 0}$ & 9 & 13,0 & $-4,0$ & & \\
\hline $\mathbf{3 , 0 0}$ & 17 & 13,0 & 4,0 & & \\
\hline $\mathbf{4 , 0 0}$ & 25 & 13,0 & 12,0 & df & 4 \\
\hline $\mathbf{5 , 0 0}$ & 4 & 13,0 & $-9,0$ & & \\
\hline Total & 65 & & & Asymp. Sig. &, 000 \\
\hline
\end{tabular}

Table 3. Digital trends VAR00003

\begin{tabular}{|c|c|c|c|c|c|}
\hline & Observed N & Expected N & Residual & & VAR00003 \\
\hline $\mathbf{1 , 0 0}$ & 1 & 10,3 & $-9,3$ & Chi-Square & $36,065^{\text {a }}$ \\
\hline $\mathbf{2 , 0 0}$ & 4 & 10,3 & $-6,3$ & & \\
\hline $\mathbf{3 , 0 0}$ & 25 & 10,3 & 15,7 & Df & 2 \\
\hline Total & 30 & & & Asymp. Sig. &, 000 \\
\hline
\end{tabular}

Table 4. Digital platforms and tools VAR00004

\begin{tabular}{|c|c|c|c|c|c|}
\hline & Observed N & Expected N & Residual & & VAR00004 \\
\hline $\mathbf{1 , 0 0}$ & 8 & 13,5 & $-5,5$ & Chi-Square & $4,222^{\mathrm{b}}$ \\
\hline $\mathbf{2 , 0 0}$ & 17 & 13,5 & 3,5 & & \\
\hline $\mathbf{3 , 0 0}$ & 17 & 13,5 & 3,5 & df & 3 \\
\hline $\mathbf{4 , 0 0}$ & 12 & 13,5 & $-1,5$ & & \\
\hline Total & 54 & & & Asymp. Sig. &, 238 \\
\hline
\end{tabular}

\section{CONCLUSION}

The significance of this research can be seen through several theoretical and practical aspects. The theoretical significance can be seen precisely through the research so far that emphasizes the importance of the competency building process itself with digital marketing managers.

The direct application of the data from the research gives us the opportunity to conclude that digital marketing managers, in addition to formal education, acquire skills and competencies for digital trends mostly in informal education. The majority attend digital training, and some need to attend it more actively to acquire greater competencies in using equipment, software and online platforms and tools needed for effective work performance.

Digital marketing is an innovative concept of the 21st century. Through this form of marketing, many products and services are promoted through the use of distribution data base driven 
network channels to reach customers in an appropriate, relevant, individual and profitable manner.

The competencies of a digital manager are not only a result of the degree obtained in this field but also a result of additional courses, training, internet optimization activities, analytics, advertising, business practices, social media, e-mail marketing, web development and writing texts.

Digital marketing managers are responsible for developing and overseeing Internet marketing strategies, ranging from small startups to large organizations. They are responsible for overseeing projects and ensuring that digital marketing campaigns run smoothly from start to finish, and are a key point of contact for customers.

\section{REFERENCES}

Anderson, P. F. (1982). Marketing, strategic planning and the theory of the firm. The Journal of Marketing, pp.15-26.

Armstrong, G., Adam, S., Denize, S., \& Kotler, P. (2014). Principles of marketing. Pearson Australia.

Chaffey, D., Smith, P. R., \& Smith, P. R. (2012). eMarketing eXcellence: Planning and optimizing your digital marketing. Routledge.

Draganidis, F., \& Mentzas, G. (2006). Competency based management: a review of systems and approaches. Information management \& computer security

European Commission. (2004). Key competences for lifelong learning, implementation of "Education and training 2010" work programme, Brussels, p.3.

Eaker. A. D. (2011). Strategic Market Management, Ars Lamina

Petkovski, K., Terzioska, V., Stefanovska, L. (2014), Active Bitola: PEN-KM Bitola, HerakliKomerc Bitola, p.3.

https://www.indeed.com/career-advice/careers/what-does-a-digital-marketing-manager-do https://www.clickatell.com/articles/digital-marketing/7-skills-digital-marketing-manager/ https://nfoaktiv.wordpress.com 